\title{
Colourfastness of Multilayer Printed Textile Materials to Artificial Light Exposure
}

\author{
Nemanja Kašiković, Dragoljub Novaković, Igor Karlović, Gojko \\ Vladić, Neda Milić
}

University of Novi Sad, Faculty of Technical Sciences, Department of Graphic engineering and design, Trg Dositeja Obradovića 6, 21000 Novi Sad, Serbia knemanja@uns.ac.rs,novakd@uns.ac.rs, karlovic@uns.ac.rs, vladicg@uns.ac.rs, milicn@uns.ac.rs

\begin{abstract}
Accuracy of colour reproduction and colourfastness are the most significant parameters of the quality of printed fabrics in the textile industry. The aim of this paper is to gain deeper insights into the colour difference of textiles printed by ink jet method before and after light exposure. In order to accomplish this, 60 samples were printed, using four process colours $(C M Y K)$ on three textile materials with different characteristics (fabric weight and thread count). Additionally, number of ink layers varied (from 1 to 5 layers). Afterwards, printed samples were exposed to the light. The colour of the samples was measured using spectrophotometer before and after exposition to the light, colour difference was calculated and afterwards analysed. Colour difference analysis has shown the significant difference of colour fastness within samples that were printed with different number of ink layers and also between different textile materials.
\end{abstract}

Keywords: ink jet printing; light exposure; colour difference

\section{Introduction}

Textile printing can be defined as the process of transferring ink to the textile substrate by using specific printing technique. The fact is that printing processes are changing rapidly and intensively [1]. That affects the textile printing industry, causing decrease of textile screen printing market share from $90 \%$ in 2000 [2] by introduction of digital ink jet textile printing that offers higher printing speed of short runs, flexibility, creativity and environment safety [3, 4]. It is important to note that using digital printing technique enables better visual effects, as well as no limitation of print formats. Besides that, it is easier to get unified print quality during the production runs $[5,6]$. Another advantage of digital ink jet is ability of printing on the great number of different substrates. One of the most often used fabric for digital printing is polyester based, especially for the manufacturing of the flags. Thermal stability, excellent behaviour during exploitation and uniform quality are characteristics that make polyester so applicable [7]. 


\section{Colour Dyeing and Printing of Textiles}

The quality of the produced image should be comparable to the quality of the printed images that are produced by the means of rotary screen printing or other printing technologies used for textile printing. The final print quality in digital textile printing depends on:

-Ink and ink system (used dyes, binders, monomers, or oligomers).

-Print head (resolution, jet straightness and nozzle reliability).

-Substrate: Depending on the type of fabric, different approaches are needed.

-Surface properties affect penetration of the inks, surface pre- and post-treatment could improve image quality, and for example dirt could cause printing artefacts.

- Fabric fixing mechanism: Motion of the fabric affects registration between dots and cause artefacts, like banding or stitching lines.

- Image processing. [8]

The choice of textile substrate influences image quality (i.e., inter-color bleed, dot quality, color, visual perception, etc.), ink drying time, and fastness (light, wet, gas, etc.). Fabric substrates are three-dimensional structures, and low viscosity inks can wick into macro-capillaries between yarns and fibers. Inks can also diffuse into the micro-capillaries in fibers.The wicking and diffusion rates are controlled by the surface tension of ink, ink viscosity, yarn and fabric structures, and the polymer morphology of the fiber. Ultimately, dye molecules in the ink droplets must be fixed on or near the surface of the textile fiber substrate for sharp and brilliant color images. The fixing mechanism depends on the dye/fiber combination [9]. Different dyes are used for the coloration of different fibers. Colour durability, such as wet-fastness and light-fastness, differs for each combination of dye and substrate. An overview of these combination is given in [10]. Several thesis investigated the structual and optical characteristics of printed textiles on the the colour reproduction [11] as well the technological improvement of digital ink jet printing regarding the aformentioned influencing factors [12] and the possibility of using novelty materials in post treatment of digital prints of textile materials for better print quality [13]. In another paper by [14] the influences of exposure of a four-layer stack of woven polyester fabrics to atmospheric pressure air plasma treatment was investigated regarding colourfastness. The research of anti bleeding property and colourstrength revealed that the atmospheric pressure plasma could substantially penetrate two layers of polyester fabrics to observably improve their ink jet printing effect.This effect also contributed to the deeper and more vivid colour and better anti-bleeding performance.

\subsection{Light Exposure of Printed Textile Samples}

Textile materials used for flag printing are exposed to different environment influences such as heat, UV radiation, moisture, washing, etc. during exploitation. 
One of the factors that has an impact on the product quality, is ability to retain colour while exposed to light over long time. This represents a great issue because final appearance of the product cannot be predicted [15]. Light exposure of printed samples causes colour differences, although structural modification of material is also possible [16]. Researchers trying to improve the lightfastness of the printed colors on the textile material deploy two possible solutions:either they can choose dyes with better lightfastness, and/or to use a UV absorber. In a paper [17] it was stated that by using UV absorbers, both water insoluble and soluble the lightfastness of inkjet printed cotton fabrics with reactive inks could improve. The water soluble UV absorber had better lightfastness improvement than the water insoluble UV absorber based on the conditions examined. Exposure of printed samples to light can be done according to standards: ISO105 - B02, ISO105-B011999, ISO105-B03 -1997, ISO105-B04-1997, ISO105-B05-1996, ISO105-B061999, ISO105-B07:2009, ISO105-B08:1999. Majority of researchers use ISO105 - B02 standard [18, 19, 20, 21, 22]. The difference between samples, exposed and unexposed to light, is usually determined visually, using the blue wool reference. However, visual judgment can not provide information accurate enough in all circumstances. The more objective way to measure colour difference changes for different colourfastness test (light,wash, rub) is a spectrophotometric method which was used by several researchers [23, 24, 25].

\section{Materials and Methods}

This paper researches the influence of light on colour prints made on three textile substrates. The experiment demanded step-by-step procedure and measurement and gathering of relevant data for detailed analysis of how light influences on printed samples. Samples were printed using digital ink jet printing technique (Mimaki JV22-160 printing system with J-Eco Subly Nano inks). The used ink are dispersed dye digital ink for direct ink jet material printing and they have good fastness properties, which makes them suitable for outdoor products printing. The interaction of the polyester and the dye is hydrophobic with solid state mechanism. The fixation is by heat when the dyes go to gaseous state and are absorbed by the printed polyester fabric and when the dyes are cooled down it enables good bonding to the polyester fibre as they can get inbetween the tightly paded polymer chains.

The colour values of samples before and after light exposure were specified by spectrophotometric measurement according to which the colour differences were calculated. As flags three types of polyester fabrics were used, mostly because of their specific characteristics including superior strength and resistance [26]. For all samples material characteristics were determined according to standards: fabric weight using standard ISO 3801, thread count (ISO 7211-2) and material composition (ISO 1833). Characteristics of used materials are shown in Table 1. 
Table 1

Characteristics of textile materials used in the experiment

\begin{tabular}{|c|c|c|c|c|}
\hline \multirow{2}{*}{ Tested samples } & Material & Fabric weight & \multicolumn{2}{|c|}{ Thread count $(\mathrm{p} / 10 \mathrm{~cm})$} \\
\cline { 4 - 5 } & composition $(\%)$ & $(\mathrm{g} / \mathrm{m} 2)$ & Warp & Weft \\
\hline Material 1 & Polyester 100\% & 110,6 & 170 & 120 \\
\hline Material 2 & Polyester 100 \% & 101,5 & 160 & 100 \\
\hline Material 3 & Polyester 100 \% & 141,3 & 260 & 120 \\
\hline Examination & ISO 1833 & ISO 3801 & \multicolumn{2}{|c|}{ ISO 7211-2 } \\
\hline
\end{tabular}

In order to analyse influence of light and heat a test card was prepared. Dimensions of test card were $150 \times 10 \mathrm{~cm}$ and consisted of 4 patches of colour, size $35 \times 10 \mathrm{~cm}$. Colour values of patches were: patch $1-100 \%$ cyan, patch $2-$ $100 \%$ magenta, patch $3-100 \%$ yellow, patch $4-100 \%$ black. Since printing system Mimaki JV $22-160$ is able to make variations in number of printed ink layers, print test card was used in five variations, from one to five ink layers. It was assumed that increase of ink layers will improve colour fastness during exploitation and longer exposure to various influences. To measure colorimetric properties of samples the spherical spectrophotometer Datacolor Spectraflash SF $600 ®$ PLUS - CT was used. This spectrophotometer features $\mathrm{D}_{65}$ standard light and standard observer $10^{\circ}$, with measuring aperture of $16 \mathrm{~mm}$. During spectrophotometric measurement, all textile samples were folded three times and set on mat white background with $\mathrm{L}^{*}>92$ and $\mathrm{C}^{*}<3$ (standard ISO13655). Every sample was measured 10 times and average value was calculated accordingly. Before starting measurement procedure spectrophotometer was tested in terms of preciseness and accuracy according to standard ASTM E2214-08 (2008) and obtained results were in tolerable extent specified by device specification. Light exposure of samples was conducted according to ISO 105-B02 standard (method 2), Xenon test chamber Alpha by manufacturer Atlas was used to simulate influence of light. Samples were exposed according to predefined conditions (temperature, exposure time, relative moisture). After exposing the samples, spectrophotometric measurements were made in order to determine colour fastness of textile samples. In order to determine statistically how material characteristic and number of ink layer influence the colour differences (CIE LCH colour space) caused by light exposure ANOVA and T tests were used. All these analyses gave guidance how to create model for simulation of light influences on specific colour that is printed on specific textile sample.

\section{Results and Discussion}

After printing process the colour coordinates CIE L (lightness), a, b, C (chroma) and $\mathrm{H}$ (hue) colour coordinates (CIE Lab and LCH colour spaces) were determined for printed sample with variations of numerous ink layers. Results in 
Table 2 represent comparison of samples printed with five ink layers and other samples to using colour difference $\Delta \mathrm{E} 76$ formula.

Table 2

Spectrophotometer measurement results

\begin{tabular}{|c|c|c|c|c|c|c|c|c|}
\hline Sample & $\mathrm{L}$ & $\mathrm{a}$ & $\mathrm{b}$ & $\mathrm{C}$ & $\mathrm{h}$ & $\Delta \mathrm{E}$ & $\begin{array}{l}\text { Pearson } \\
\text { correlat } \\
\text { ion } \\
(\mathrm{L} \text { and } \\
\text { ink } \\
\text { layer }\end{array}$ & $\begin{array}{l}\text { Pearson } \\
\text { correlation } \\
\text { (C and ink } \\
\text { layer } \\
\text { number) }\end{array}$ \\
\hline $1-1 \mathrm{C}$ & 48.29 & -7.29 & -31.13 & 31.97 & 256.82 & 16.7 & \multirow[b]{5}{*}{-0.99} & \multirow[b]{5}{*}{-0.97} \\
\hline $1-2 C$ & 43.78 & -6.09 & -27.7 & 28.36 & 257.6 & 11.1 & & \\
\hline $1-3 C$ & 39.94 & -5.82 & -25.95 & 26.6 & 257.36 & 6.9 & & \\
\hline $1-4 C$ & 36.15 & -5.29 & -24.75 & 25.31 & 257.94 & 2.89 & & \\
\hline $1-5 \mathrm{C}$ & 33.5 & -4.72 & -23.74 & 24.2 & 258.77 & 1 & & \\
\hline $1-1 \mathrm{M}$ & 46.74 & 48.71 & 0.88 & 48.72 & 1.03 & 16.3 & \multirow[b]{5}{*}{-0.98} & \multirow[b]{5}{*}{-0.98} \\
\hline $1-2 \mathrm{M}$ & 41.34 & 44.94 & 2.95 & 45.03 & 3.76 & 9.56 & & \\
\hline $1-3 \mathrm{M}$ & 39.24 & 41.96 & 2.59 & 42.04 & 3.53 & 6.2 & & \\
\hline $1-4 \mathrm{M}$ & 36.54 & 40.27 & 3.45 & 40.42 & 4.9 & 2.91 & & \\
\hline $1-5 \mathrm{M}$ & 34.37 & 38.54 & 4.33 & 38.78 & 6.41 & 1 & & \\
\hline $1-1 Y$ & 78.28 & -2.73 & 65.72 & 65.77 & 92.38 & 16.5 & \multirow[b]{5}{*}{-0.99} & \multirow[b]{5}{*}{0.94} \\
\hline $1-2 Y$ & 74.64 & 1.78 & 68.71 & 68.73 & 88.52 & 10.1 & & \\
\hline $1-3 Y$ & 72.02 & 4.39 & 70.92 & 71.05 & 86.46 & 6.03 & & \\
\hline $1-4 \mathrm{Y}$ & 69.81 & 6.78 & 71.71 & 72.03 & 84.6 & 2.73 & & \\
\hline $1-5 Y$ & 68.03 & 8.84 & 71.67 & 72.22 & 82.97 & 1 & & \\
\hline $1-1 \mathrm{~K}$ & 36.04 & -0.33 & -1.18 & 1.23 & 254.56 & 13.8 & \multirow[b]{5}{*}{-0.96} & \multirow[b]{5}{*}{-0.91} \\
\hline $1-2 \mathrm{~K}$ & 30.01 & -0.65 & -0.91 & 1.12 & 234.55 & 7.85 & & \\
\hline $1-3 \mathrm{~K}$ & 25.68 & -0.4 & -1.02 & 1.1 & 248.63 & 3.52 & & \\
\hline $1-4 \mathrm{~K}$ & 23.35 & -0.58 & -0.95 & 1.11 & 238.68 & 1.19 & & \\
\hline $1-5 \mathrm{~K}$ & 22.16 & -0.51 & -0.88 & 1.02 & 239.54 & 1 & & \\
\hline $2-1 \mathrm{C}$ & 44.21 & -4.32 & -31.74 & 32.03 & 262.25 & 18.9 & \multirow[b]{5}{*}{-0.97} & \multirow[b]{5}{*}{-0.95} \\
\hline $2-2 \mathrm{C}$ & 37.11 & -2.44 & -27.27 & 27.38 & 264.88 & 10.4 & & \\
\hline $2-3 C$ & 34.42 & -0.02 & -24.02 & 24.02 & 269.95 & 6.3 & & \\
\hline $2-4 \mathrm{C}$ & 30.73 & -1.23 & -23.17 & 23.2 & 266.96 & 2.74 & & \\
\hline $2-5 C$ & 28.62 & -0.46 & -21.6 & 21.6 & 268.79 & 1 & & \\
\hline $2-1 \mathrm{M}$ & 43.07 & 49.59 & 1.55 & 49.62 & 1.79 & 18.7 & \multirow[b]{5}{*}{-0.95} & \multirow[b]{5}{*}{-0.96} \\
\hline $2-2 \mathrm{M}$ & 36.49 & 42.8 & 3.12 & 42.92 & 4.17 & 9.29 & & \\
\hline $2-3 \mathrm{M}$ & 32.81 & 38.87 & 5.51 & 39.26 & 8.06 & 4.55 & & \\
\hline $2-4 \mathrm{M}$ & 32.79 & 38.66 & 5.12 & 39 & 7.55 & 4.21 & & \\
\hline $2-5 \mathrm{M}$ & 29 & 32.36 & 5.28 & 32.79 & 9.26 & 1 & & \\
\hline $2-1 Y$ & 77.17 & 4.82 & 75.02 & 75.18 & 86.32 & 20.8 & \multirow{5}{*}{-0.99} & \multirow[b]{5}{*}{-0.96} \\
\hline $2-2 Y$ & 71.77 & 4.82 & 75.02 & 75.18 & 86.32 & 15.0 & & \\
\hline $2-3 Y$ & 67.91 & 6.93 & 72.02 & 72.36 & 84.5 & 10.0 & & \\
\hline $2-4 Y$ & 64.85 & 8.49 & 68.91 & 69.43 & 82.98 & 5.77 & & \\
\hline $2-5 Y$ & 62.31 & 8.95 & 65.05 & 65.66 & 82.17 & I & & \\
\hline $2-1 \mathrm{~K}$ & 27.28 & -0.3 & -0.14 & 0.33 & 205.02 & 6.4 & \multirow[b]{2}{*}{-0.93} & \multirow[b]{2}{*}{-0.77} \\
\hline $2-2 \mathrm{~K}$ & 23.81 & -0.43 & -0.14 & 0.45 & 198.29 & 2.96 & & \\
\hline
\end{tabular}




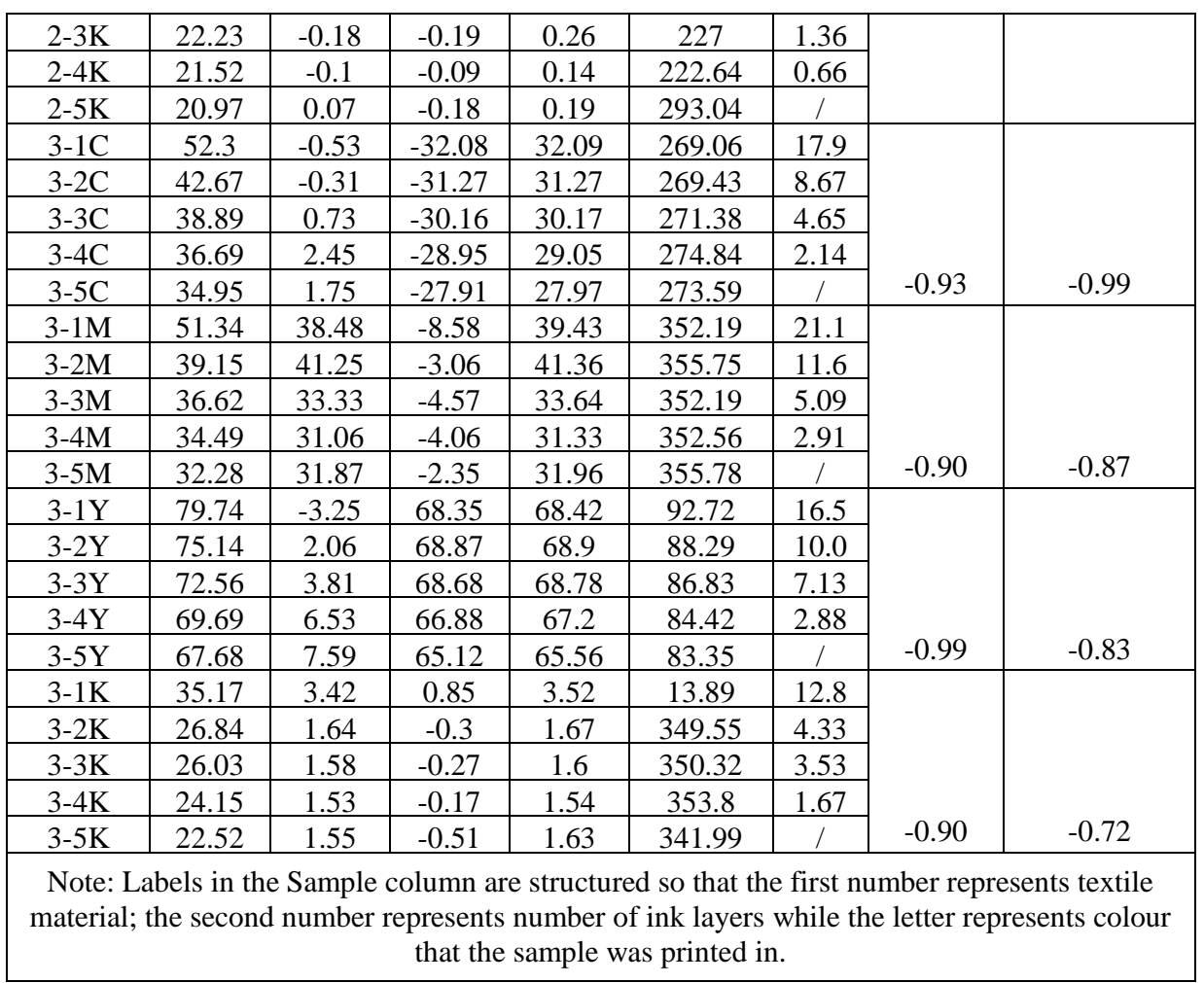

Results presented in table 2 show that increasing number of ink layers during print leads to decreasing of lightness and saturation at all four process colours. Changes of lightness and saturation have linear tendency with a high value of correlation coefficient. Therefore, colour difference value will rise with change of ink layer number.The lowest values of $\Delta \mathrm{E}$ were calculated for black colour for all materials, while samples printed by cyan, magenta and yellow showed higher values of $\Delta \mathrm{E}$, similar across all materials. Colour difference values where mostly greater than 5 , $\Delta \mathrm{E}>5$, except in comparison with samples printed with four and five ink layers. Based on linear tendency of lightness and saturation changes it can be assumed that further increase in number of ink layer number will increase value $\Delta \mathrm{E}$ also.

\subsection{Spectrophotometric Measurement after Light Exposure}

After printed samples had been exposed to light according to ISO105-B02 standard (method 2) (temperature, lightness, moisture) the spectrophotometric measurements were conducted in order to determine how the exposure to light influenced changes in sample colour. The earlier researches regarding similar subject [22] proved that increased number of ink layers is increasing light fastness, although limited to visual assessment of colour changes. It was expected that spectrophotometric measurements confirm results gained by visual analysis. This 
practically means that samples assessed with higher grade of colour fastness would have lower colour difference values after light exposure. The table 3 represents resulting differences of colour coordinates $\Delta \mathrm{L}, \Delta \mathrm{a}, \Delta \mathrm{b}, \Delta \mathrm{C}$ and $\Delta \mathrm{h}$ of samples.

Table 3

Differences of colour coordinates before and after light exposure

\begin{tabular}{|c|c|c|c|c|c|}
\hline Sample & $\Delta \mathrm{L}$ & $\Delta \mathrm{a}$ & $\Delta \mathrm{b}$ & $\Delta \mathrm{C}$ & $\Delta \mathrm{h}$ \\
\hline $1-1 \mathrm{C}$ & 0.87 & 2.58 & 2.78 & 3.24 & 4.76 \\
\hline $1-2 \mathrm{C}$ & 1.53 & 2.28 & 2.73 & 3.15 & 4.48 \\
\hline $1-3 \mathrm{C}$ & 0.79 & 2.15 & 2.84 & 3.23 & 4.37 \\
\hline $1-4 \mathrm{C}$ & 1.2 & 2.38 & 2.23 & 2.65 & 5.71 \\
\hline $1-5 \mathrm{C}$ & 0.69 & 1.83 & 2.47 & 2.78 & 4.06 \\
\hline $1-1 \mathrm{M}$ & 1.59 & 1.07 & 0.57 & 1.11 & 0.6 \\
\hline $1-2 \mathrm{M}$ & 1.2 & 1.46 & 0.45 & 1.49 & 0.44 \\
\hline $1-3 \mathrm{M}$ & 0.85 & 1.28 & 0.52 & 1.31 & 0.51 \\
\hline $1-4 \mathrm{M}$ & 1.42 & 0.53 & -0.11 & 0.52 & -0.16 \\
\hline $1-5 \mathrm{M}$ & 0.88 & 0.66 & 0.38 & 0.68 & 0.36 \\
\hline $1-1 \mathrm{Y}$ & 1 & -0.43 & -2.25 & 2.27 & 0.3 \\
\hline $1-2 \mathrm{Y}$ & 1.39 & -0.74 & -1.76 & 1.78 & 0.82 \\
\hline $1-3 Y$ & 2.02 & 0.15 & 1.19 & 1.2 & 0.01 \\
\hline $1-4 \mathrm{Y}$ & 1.39 & -0.29 & -0.52 & 0.55 & 0.24 \\
\hline $1-5 \mathrm{Y}$ & 1.37 & -0.21 & 0.06 & 0.04 & 0.21 \\
\hline $1-1 \mathrm{~K}$ & 4.02 & 1.8 & -0.57 & 1.84 & - \\
\hline $1-2 \mathrm{~K}$ & 3.33 & 1.63 & -0.78 & 1.8 & - \\
\hline $1-3 K$ & 3 & 1.78 & -0.18 & 1.61 & - \\
\hline $1-4 \mathrm{~K}$ & 2.17 & 2.07 & 0.05 & 1.74 & - \\
\hline $1-5 \mathrm{~K}$ & 1.74 & 2.35 & 0.43 & 1.77 & - \\
\hline $2-1 C$ & 2.14 & 1.36 & -0.32 & 0.11 & 3.91 \\
\hline $2-2 C$ & 1.53 & 1.92 & 0.03 & 0.31 & 4.82 \\
\hline $2-3 \mathrm{C}$ & 0.39 & 1.99 & 0.27 & 0.62 & 4.17 \\
\hline $2-4 \mathrm{C}$ & 0.52 & 1.23 & -0.53 & 0.37 & 3.84 \\
\hline $2-5 \mathrm{C}$ & 1.12 & 0.76 & -0.32 & 0.22 & 2.5 \\
\hline $2-1 \mathrm{M}$ & 0.73 & 4.13 & 0.28 & 4.14 & -0.16 \\
\hline $2-2 M$ & 2.48 & 2.83 & 0.08 & 2.83 & -0.23 \\
\hline $2-3 \mathrm{M}$ & 2.76 & 0.79 & 0 & 0.78 & -0.07 \\
\hline $2-4 \mathrm{M}$ & 1.58 & 2.18 & 0.23 & 2.19 & 0 \\
\hline $2-5 \mathrm{M}$ & 0.81 & 2.15 & -0.22 & 2.13 & -0.35 \\
\hline $2-1 Y$ & 4.4 & -1.22 & 6.42 & 6.26 & 1.74 \\
\hline $2-2 Y$ & 3.92 & -1.55 & 4.73 & 4.6 & 1.78 \\
\hline $2-3 Y$ & 3.84 & -0.66 & 4.56 & 4.43 & 1.22 \\
\hline $2-4 Y$ & 3.09 & -1.33 & 2.76 & 2.7 & 1.39 \\
\hline $2-5 Y$ & 1.81 & -0.92 & -0.21 & 0.21 & 0.92 \\
\hline $2-1 \mathrm{~K}$ & 2.64 & 0.71 & 0.01 & 0.69 & - \\
\hline $2-2 \mathrm{~K}$ & 2.19 & 1.07 & 0.21 & 1.02 & - \\
\hline $2-3 K$ & 1.9 & 1.35 & -0.04 & 1.34 & - \\
\hline $2-4 \mathrm{~K}$ & 1.92 & 1.26 & 0.14 & 1.18 & - \\
\hline $2-5 \mathrm{~K}$ & 1.82 & 1.12 & 0.43 & 1.01 & - \\
\hline
\end{tabular}




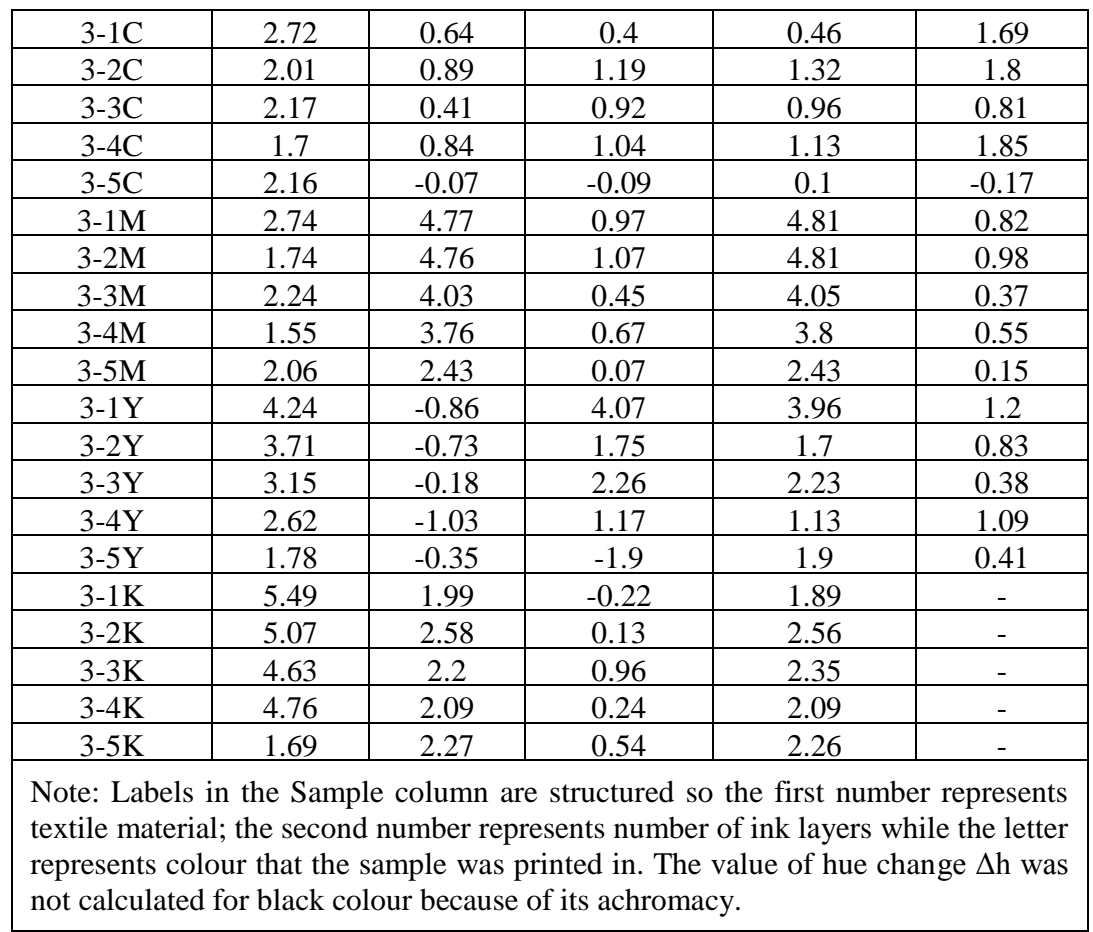

Values of $\Delta \mathrm{E}$ are grouped according to colour and presented on Figure 2.
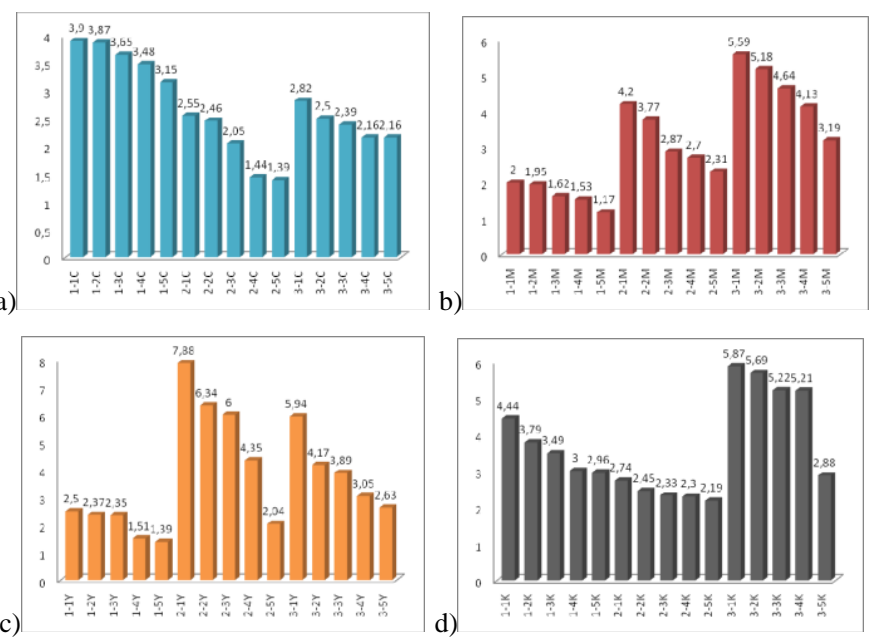

Figure 2

Value $\Delta \mathrm{E}$ between unexposed and light exposed samples - all textiles printed by: a) cyan, b) magenta, c) yellow d) black colour 
Figure 2 indicates that increased number of ink layers during printing cause better light fastness compared to samples printed with lower number of ink layers, as it was concluded by preliminary researches [22]. This can be concluded since the highest value of $\Delta \mathrm{E}$ was recorded after light exposure of the sample that was printed in one ink layer, while the lowest value of $\Delta \mathrm{E}$ was marked after light exposure of the sample printed in five ink layers.

In order to determine how ink layers, material characteristics (fabric weight and thread count) and type of ink influenced colour difference $(\Delta \mathrm{E})$, ANOVA analysis was conducted followed by Tukey tests. Although ANOVA test, as all parameter tests, has assumption about normal distribution of sample group, it is very robust and in case of bigger samples it does not cause any significant problems [27]. The two-way ANOVA with material characteristics and ink layer number as between subject factors showed no interactive effect of the two factors, Using one-way ANOVA statistically significant colour difference was determined depending on type of textile material, $F(2,57)=4.130, p=0.021$. Post-hoc tests showed that statistical difference existed between material $3(\mathrm{M}=3.97, \mathrm{SD}=1.36)$ and material $1(\mathrm{M}=2.71, \mathrm{SD}=0.99)$, while material $2(\mathrm{M}=3.22, \mathrm{SD}=1.73)$ did not differ significantly from other samples. Furthermore, statistically significant difference in change of lightness was determined depending on number of ink layers, $\mathrm{F}(4,55)$ $=3.552, \mathrm{p}=0.012$. Post-hoc tests showed that there was significant difference between samples with one $(\mathrm{M}=4.20, \mathrm{SD}=1.81)$ and with five ink layers $(\mathrm{M}=$ $2.29, \mathrm{SD}=0.7)$, while the group of samples with two $(\mathrm{M}=3.71, \mathrm{SD}=1.44)$, three $(\mathrm{M}=3.37, \mathrm{SD}=1.36)$ and four layers $(\mathrm{M}=2.90, \mathrm{SD}=1.21)$ did not differ from one to another and did not differ from samples with one and with five ink layer.

Figure 3 represents graphs of colour difference that are grouped by influence factors: a) textile and b) number of ink layers.

a)

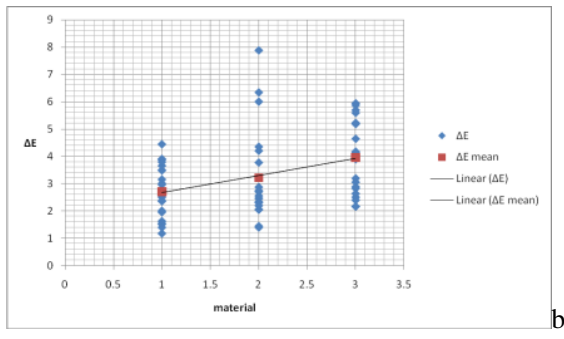

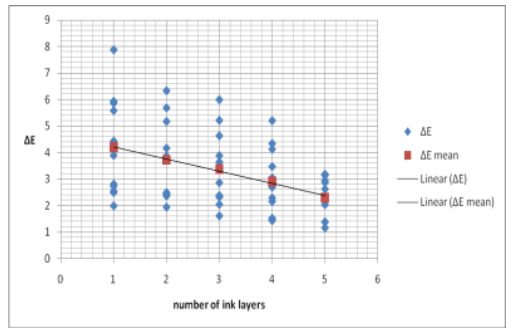

b)

Figure 3

Colour difference graphs grouped by factors: a) material, b) number of ink layers

The Pearson correlation coefficients between values of lightness and chroma before and after light exposure including all 60 samples were both high -0.998 , with corresponding coefficient of determination of 0,995 pointing to possibility of creating simulation model for colour appearance after light exposure. This is an important result since it means that according colour fastness behaviour of just one sample, the lightness and chroma changes of any sample can be predicted. 
The graphics of these linear correlations with equations are show on Figure 4 . From obtained results can be deducted that significant difference in colour change after light exposure, $\Delta \mathrm{E}$, is caused by different colour values of samples before light exposure on samples with different thread count and printed with different ink layer number.

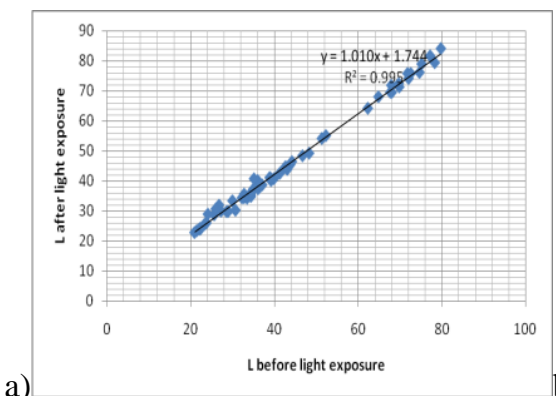

a)

b)

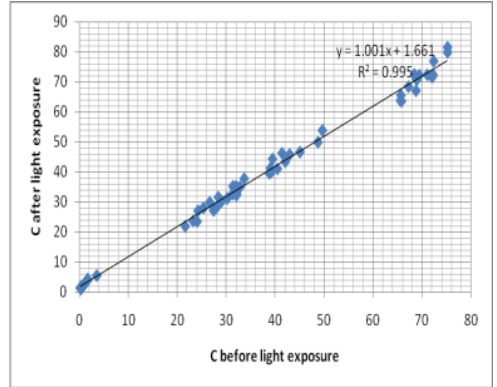

Figure 4

Correlation of values before and after light exposure for: a) lightness, b) chroma

\section{Conclusion}

Researching the light influence on printed materials has been a field of concern to many researches in textile dying and printing. The aim of these researcher were to prolong the use of the printed or dyed product with intact colour deviations. The use of digital ink jet printers enable multi passs printing with different number of layers. This reasearch focused on spectrophotometric measurement assessment of the influence of multiple printed layers. Exposure to light of printed samples showed that increased number of ink layers increases colour fastness, spectrophotometric measurement showed lower colour difference. The highest values of $\Delta \mathrm{E}$ were calculated for samples made by only one ink layer, while the lowest values were marked on light exposed samples with five ink layers. This can be explained by a greater number of ink particles on the surface. Moreover, colour differences between samples printed with five ink layers and all other samples were calculated. The greatest colour difference was noted between samples with one and five ink layers $(\Delta \mathrm{E}>6)$, and the smallest one was between samples made of four and five ink layers $(\Delta \mathrm{E}<6)$.

Also, characteristics of substrate have been proven to be important influential factor for light fastness and therefore cannot be ignored.

According to results of the research, it is recommended to take into consideration number of ink layers when choosing digital printing techniques in order to achieve high quality. If extended colourfastness is needed additional layers of the ink can be applied to the substrate. The other point is that spectrophotometric measurement can be better solution then visual assessments, since it provides more accurate results. Numerical values gathered from instrumental measurements are more suitable for quantification of values and colour management and are 
more easily controlabble by digital ink jet printer than in classic textil dying. Regardless of the results, the importance of visual assessment cannot be disputed since the end user is a human.

\section{Acknowledgement}

This work was supported by the Serbian Ministry of Science and Technological Development, Grant No.:35027 "The development of software model for improvement of knowledge and production in graphic arts industry"

\section{References}

[1] Neral B., Šostar Turk S., Schneider R. Efikasnost mikrovalnog fiksiranja reaktivnog bojila C.I. Reactive Red 24 u digitalnom tisku pamučnih tkanina, In: Tekstil, 2007, Vol. 56, Issue 6, 2007, p. 358

[2] Horrocks, A. R. (ed.). Handbook of Technical Textiles, The Textile Institute, Woodhead Pub. Ltd., Cambridge, UK, 2000

[3] Choi P. S. R., Yuen C. W. M., Ku S. K. A., Kan C. W. Digital Ink-jet Printing for Chitosan-treated Cotton Fabric, In: Fibers and Polymers, 2005, Vol. 6, Issue 3, p. 229

[4] Masaru O., Kazuhide Y., Yukio A. Textile Printing by the Ink-Jet Printer, In: Nihon Gazo Gakkaishi/Journal of the Imaging Society of Japan, 2010, Vol. 49, Issue 5, p. 417

[5] Owen P. Digital Printing: A World of Opportunity from Design to Production, In: AATCC Review, 2003, Vol. 3, Issue 9, p. 10

[6] Xue C. H, Shi M. M, Chen H. Z. Preparation and Application of Nanoscale Micro Emulsion as Binder for Fabric Inkjet Printing, In: Colloids and Surfaces A: Physicochemical. Eng. Aspects, 2006, Vol. 287, Issue 1-3, p. 147

[7] Ristić N., Ristić I., Jovaničić P., Jocić D. One-Bath Dyeing of Polyester/Cotton Blend with Reactive Dye after Alkali and Chitosan Treatment, In: Industria Textila, 2012, Vol. 63, Issue 4, p. 190

[8] Phillips T. Revolutionizing Textile Decoration and Finishing with Ink Jet Technology [online]. Talk given at Textile Coating \& Laminating Conference. Xennia Technology Ltd: Cannes; November 2010. [Online] URL: http://www.xennia.com/uploads/pppRevolutionisingTextileDecorationNov2010-sml.pdf. [Accessed 6 April 2013]

[9] Kim Y. K. Effect of Pretreatment on Print Quality and Its Measurement, Digital Printing of Textiles, H. Ujiie Ed., Woodhead Publishing, Cambridge, England, p. 256 
[10] Provost J, Freche M., Hees U., Kluge M., Weiser J.: Ink-Textile Interactions in Ink Jet Printing-The Role of Pretreatments, 2003 [Online] URL: http://provostinkjet.com/resources/SDC\%2B\%2BInk\%2BJetPretreatment\%2B4th\%2BD ec\%2B03.pdf [Accessed 13 April 2013]

[11] Jihyun B.: Color in Ink-Jet Printing: Influence of Structural and Optical Characteristicsof Textiles., PhD thesis, North Carolina State University, 2007 [Online]

URL: http://repository.lib.ncsu.edu/ir/bitstream/1840.16/4425/1/etd.pdf [Accessed 13 April 2013]

[12] Choi P.S. Development of Optimum Printing System for Digital Ink Jet Printing, Hong Kong Polytechnic University, Master thesis, 2006 [Online] URL: http://hdl.handle.net/10397/3157 [Accessed 11 May 2013]

[13] Momin H. N. Chitosan and Improved Pigment Ink Jet Printing on Textiles, $\mathrm{PhD}$ Thesis, School of Fashion and Textiles, RMIT University, 2008, [Online] URL: http://researchbank.rmit.edu.au/eserv/rmit:6752/Momin.pdf [Accessed 13 May 2013]

[14] Zhang C. M., Fang K. J.: Influence of Penetration Depth of Atmospheric Pressure Plasma Processing into Multiple Layers of Polyester Fabrics on Ink Jet Printing, Surface Engineering, Volume 27, Number 2, March 2011, pp. 139-144(6)

[15] Herascu N., Simileanu M., Radvan R. Colour Changes in the Artwork Materials Aged by UV radiation, In: Romanian Reports in Physics, 2008, Vol. 60, Issue 1, p. 95

[16] Morent R., De Geytern, Verschuren J., De Clerck K., Kiekens P., Leys C. Non-Thermal Plasma Treatment of Textiles, In: Surface and Coatings Technology, 2008, Vol. 202, Issue 14, p. 3427

[17] Yiqi Y., Vamshi N.: Improvement of the Lightfastness of Reactive Inkjet Printed Cotton, Dyes and Pigments, 74,1, 2007, pp. 154-160, http://dx.doi.org/10.1016/j.dyepig.2006.01.030

[18] Vizárová K., Reháková M., Kirschnerová S., Peller A., Simonb P., Mikulásik R., Stability Studies of Materials Applied in the Restoration of a Baroque Oil Painting, In: Journal of Cultural Heritage, 2011, Vol. 12, Issue 2, p. 190

[19] Varesano A., Tonin C. Improving Electrical Performances of Wool Textiles: Synthesis of Conducting Polypyrrole on the Fiber Surface, In: Textile Research Journal, 2008, Vol. 78, Issue 12, p. 1110

[20] Zarkogianni M., Mikropoulou E., Varellab E., Tsatsaroni E. Colour and Fastness of Natural Dyes: Revival of Traditional Dyeing Techniques, In: Coloration Technology, 2010, Vol. 127, Issue 1, p. 18 
[21] Gun A. D., Tiber B. Colour, Colour Fastness and Abrasion Properties of 50/50 Bamboo/Cotton-blended Plain-knitted Fabrics in Three Different Stitch Lengths, In: Textile research journal, 2011, Vol. 81, Issue 18, p.1903

[22] Kašiković N., Novaković D., Karlović I, Vladić G. Influence of Ink Layers on the Quality of Ink Jet-printed Textile Materials, In: Tekstil ve konfeksiyon, 2012, Vol. 22, Issue 2, p. 115

[23] Kan C. W., Yuen C. W. M.,Tsoi W. Y.,Chan C. K.: Ink-Jet Printing for Plasma-treated Cotton Fabric with Biomaterial, ASEAN Journal of Chemical Engineering, Vol. 11, No. 1 (2011) pp 1-7

[24] Rat B., Majnarić I., Možina K.: Visibility of Care Labelling Code Symbols, Tekstil: Journal of Textile \& Clothing Technology; Jun 2011, Vol. 60, Issue 6, p. 251

[25] Mikuž M., Šostar-Turk S., Pogačar V., Transfer of Ink-jet Printed Textiles for Home Furnishing into Production with Rotary Screen Printing Method, FIBRES \& TEXTILES in Eastern Europe January / December 2005, Vol. 13 , No. $6(54)$

[26] Zhang C, Fang K. Surface Modification of Polyester Fabrics for Inkjet Printing with Atmospheric-Pressure Air/Ar Plasma, In: Surface and Coatings Technology, 2009, Vol. 203, Issue 14, p. 2058

[27] Pallant J. SPSS Survival Manual, Allen \& Unwin, Crows Nest NSW 2065, Australia, 2011 